\title{
Determination of ceiling doses of Heligmosomoides bakeri infections in outbred albino mice: the maximum tolerated dose.
}

\author{
Ngongeh, Lucas Atehmengo \\ Department of Veterinary Microbiology and Parasitology, College of Veterinary Medicine, Michael Okpara \\ University of Agriculture, Umudike, Abia State, Nigeria.
}

\begin{abstract}
The maximum dose of Heligmosomoides bakeri that can be tolerated by outbred albino mice was determined. Due to the extensive works of the author of this study with Heligmosomoides bakeri infections in the outbred albino mice, researchers have often contacted him for guides in choosing safe working dose levels of the parasite. This study was conducted in order to be able to advise accurately such requests and making available such results by publication for easy and wide access. This was done in two separate experiments in which maximum infection levels of $1000 \mathrm{~L} 3$ and $4000 \mathrm{~L} 3$ respectively were used. In Experiment I all infected mice survived. However, in Experiment II, some mortalities occurred in mice infected with $2500-4000 \mathrm{~L} 3 \mathrm{H}$. bakeri. Though only proportionate to a certain point, there was generally an increase dose increase faecal egg counts (FEC) and worm burden (WB) response pattern. Also observed was an increase dose increase in PCV and bodyweight decline. This is an indication that these parameters are dependent on the infection dose levels. This fact was supported by the high morbidity and high mortality rate that occured at higher doses. The results therefore suggest that adult mice up to 8 week-old can survive infection with $2000 \mathrm{~L} 3 \mathrm{H}$. bakeri and below. The infection dose of $2000 \mathrm{~L} 3$ is therefore the ceiling dose of H. bakeri in such adult or older mice. Dose levels as high as $2500 \mathrm{~L} 3$ and above were lethal to the mice. In designing experiments with the H. bakeri-mouse model for the study of GI nematode parasites only doses of $2000 \mathrm{~L} 3$ and below should be considered. Infection doses of H. bakeri greatrer than 2000 L3 may lead to earlier death of the mice when enough data might not have been taken.
\end{abstract}

\section{Introduction}

Heligmosomoides bakeri-mouse model is an important laboratory model for chronic nematode infections due to its long lasting infections in mice. However, it is not known what dose range of $\mathrm{H}$. bakeri outbred albino mice would harbour without causing death to it thereby allowing for the desired long lasting infections in adult mice. Epidemiological processes including infection, host survival, fecundity and within-host reproduction of a parasite have been found to depend on the size of parasite inoculum to which the host is exposed to (Michael and Bundy, 1989; Asworth et al., 1996; Roland et al., 2002). In parasitic infections the parasite-induced effects on host fecundity, host survival and parasite reproduction rate within the hosts are negatively correlated with the parasite dose (Anderson and May, 1982; Keymer, 1982; Michael and Bundy, 1989; Asworth et al., 1996). Parasite virulence is also said to generally increase with the dose, whereas the reproduction rate of the parasite within the host tends to be negatively correlated with the parasite dose (Anderson and May, 1982; Keymer, 1982; Michael and Bundy, 1989; Asworth et al., 1996; Roland et al., 2002). A strong positive correlation $(\mathrm{r}=0.73, \mathrm{p}<0.01)$ was obtained between the mean strongyle worm burden and the eggs per gramme of faeces (Fakae, 1990). Here we investigate the ability of outbred albino mice to cope with increasing doses of $H$. bakeri and thereby determine the highest dose of $H$. bakeri that adult (8-10 week old) outbred albino mice can withstand in chronic infections without death as a guide in designing long lasting infections of the model.

Studies conducted using the model have often adopted lower doses such as 50-250 H. bakeri L3 (Jennifer et al., 2011). Ngongeh (2011) had infected mice with H. bakeri dose range of 100-300L3 and observed a graded response based on both pathological and parasitological parameters. Keymer and Tarlton (1991) also observed that the accumulation of $H$. bakeri was proportional to the infection pressure especially during protein malnutrition. Infection of mice with varying doses of $H$. polygyrus resulted in a graded response as has been reported in other domestic livestock (Soulsby, 1982; Ngongeh, 2010). Musongong et al. (2004) has reported that rabbits given a primary infection with Trichostrongylus colubriformis, the percentage of worm recovery 7-28 days post infection was inversely proportional to the size of the larval inoculum. An inverse inoculum size and worm burden relationship has also been shown in lambs with primary H. contortus infection (Flemming, 1988). Fatal strongylidosis (Strongyloides papillosus infection) in calves was reported in southern Japan and it was shown experimentally that calves exposed to more than $10000 \mathrm{~L} 3 / \mathrm{kg}$ body weight died (Taira et al., 1992). An infection dose of $\mathrm{H}$. bakeri that can cause clinical disease in mice is known (Ehrenford, 1954). However, it is not known what dose of $\mathrm{H}$. bakeri could cause mortality or out-rightly kill a mouse particularly prior to the 
prepatent period. In this study two separate experiments were conducted to determine the H. bakeri dose above which mortalities could occur and therefore the ceiling dose the parasite can support without dying. It was hoped that the results especially if published would be widely available and help to adequately address requests of some researchers who due to the author's extensive works with $H$. bakeri infections in the outbred albino mice have often contacted him for guides in choosing safe working dose levels of the parasite .

\section{Materials and methods}

Two separate experiments were performed to determine the ceiling dose for chronic $H$. bakeri infections in mice. In the first experiment in which 400-1000L3 of H. bakeri were used, no mortality was recorded. This was the rationale for conducting the second experiment in which mice were infected with 12004000L3.

\section{Experiment I}

Infection of mice with $H$. bakeri

Experimental animals

Thirty 8 week old male outbred albino mice weighing averagely $29 \mathrm{~g}$ at the start of the experiment were used. They were maintained in cages containing wood shavings with a maximum of 10 mice per cage to avoid overcrowding. Litter was replaced every two days with dry fresh wood shavings and equipment was cleaned. The mice well were fed and watered ad libitum. They were fed with standard pelleted growers mash (Guinea Feed®- compounded by Bendel Feed and Flour Mill-Nigeria). The mice were managed according to the departmental guidelines for handling experimental animals and in line with Nigerian guideline managing experimental animals. The design of the experiment including the schedule of infection is as presented in Table 1.

Table1. Infection of male outbred albino mice with graded single doses of H. bakeri L3.

\begin{tabular}{llllllll}
\hline Group & $\begin{array}{l}\text { Number } \\
\text { mice }\end{array}$ & of & Sex & $\begin{array}{l}\text { Age } \\
\text { mice/weeks }\end{array}$ & $\begin{array}{l}\text { of } \\
\text { L3 }\end{array}$ & $\begin{array}{l}\text { Day of } \mathrm{Hb} \text { of } \\
\text { infection }\end{array}$ & $\begin{array}{l}\text { Day of Necropsy } \\
\text { infection) }\end{array}$ \\
\hline Infected & 5 & $\mathrm{M}$ & 8 & 400 & 0 & 28 & 28 \\
Infected & 5 & & $\mathrm{M}$ & 8 & 600 & 0 & 28 \\
Infected & 5 & $\mathrm{M}$ & 8 & 800 & 0 & 28 \\
Infected & 5 & $\mathrm{M}$ & 8 & 1000 & 0 & 28 \\
Uninfected & 5 & $\mathrm{M}$ & 8 & 0 & 0 & 28 \\
\hline
\end{tabular}

$\mathrm{M}=$ Male. $\mathrm{Hb}=$ H. bakeri $. \mathrm{L} 3=$ Third larval stage (infective larvae).

Infection of mice with $H$. bakeri

The mice were infected orally with $H$. bakeri infective larvae (L3), with doses ranging from 200 L3 suspended in $200 \mu \mathrm{l}$ of distilled water. To obtain accurate dosage, properly mixed known volumes of larval suspension were administered to $\mathrm{p}$ restrained mice using automatic micropipette (Finnpippette ${ }^{\circledR}$; Labsystems Oy, Helsinki, Finland ) adapted to take a blunt and slightly curved 19-gauge needle (Fakae et al., 2001).

\subsection{Faecal egg counts}

One gramme of faeces collected as described in section 3.3 from each mouse was dispersed in $15 \mathrm{ml}$ of saturated sodium chloride solution of specific gravity 1.200. The suspension was passed through a coffee strainer and made up to $45 \mathrm{ml}$ with additional salt solution. Well-mixed aliquots were counted in a standard McMaster counter slide (Hawksley, England) and expressed as eggs per gram (epg) of faeces (MAFF, 1997).

\subsection{Body weight}

Mice were weighed weekly from the first day of each experiment using a desktop balance (Sartorius GMBH Gottingen Germany).

\subsection{Haematology}

Packed cell volume (PCV) was carried out weekly from day zero (D0) till the end of the experiment. Mice were bled from the tail directly into heparinised capillary tubes (Camlab Ltd, Cambridge).

Mortalities

Following infection mice were monitored for morbidity and mortalities mice in any group were recorded. Necropsy

Post mortem worm counts procedures were according to the methods of Fakae (1993), Ngongeh (2011) and Ngongeh and Ndofor (2011). Briefly, each mouse was sacrificed with diethyl-ether and the gastrointestinal tract was quickly removed. Up to three quarters or entire length of the small intestine starting from the 
duodenum was opened by cutting along its longitudinal axis with a pair of fine scissors. The adult worms from the intestine were recovered by suspending each intestine on a fine thread and dipping into Hanks balanced salt solution (HBSS) in a universal bottle, and the thread supported by fastening its free ends between the universal bottle and its cap, and then incubated at $37^{\circ} \mathrm{C}$. This arrangement allowed the worms to drop freely to the bottom of the bottle after leaving the intestine. Within 2-3 hours all worms would have migrated into the saline. The intestine was then discarded, after little agitation to ensure that no worm was being trapped by any two apposed sections of the gut, and fresh saline added. After removal of the intestine the incubation of the worm suspension continued overnight ( 20 hours) to ensure complete disentanglement of the worms. At the end of the overnight incubation saturated sodium chloride was added to the Hanks saline containing the worms to make up a $30 \% \mathrm{v} /$ $\mathrm{v}$ solution. The worms then died within 30 minutes of this treatment, relaxing the tight spiral coils characteristic of the live worms, thus making counting easier. The volume of the suspension was reduced to $5 \mathrm{ml}$ and poured into a clean ruled petridish. All the worms present in each sample were counted individually noting their sexes.

\section{Statistical analysis}

Results were analysed by Analysis of Variance (ANOVA) in general linear model (GLIM) and results were summarised as arithmetic means with standard errors of means (SEM).

\section{Faecal egg counts}

\section{Results}

The FEC generally rose although with some fluctuations from day (D) 12 to D28 (Fig 1). There was a dose related response in FEC in which the 1000L3 had the highest FEC, and 400L3 had the least FEC and the difference in FEC between groups was highly significant $(P=0.02)$. The 600 and $800 \mathrm{~L} 3$ doses had moderate FEC but the FEC were higher in the 800L3 than in the 600L3 dose group especially towards the end of the experiment on D24 and D28.

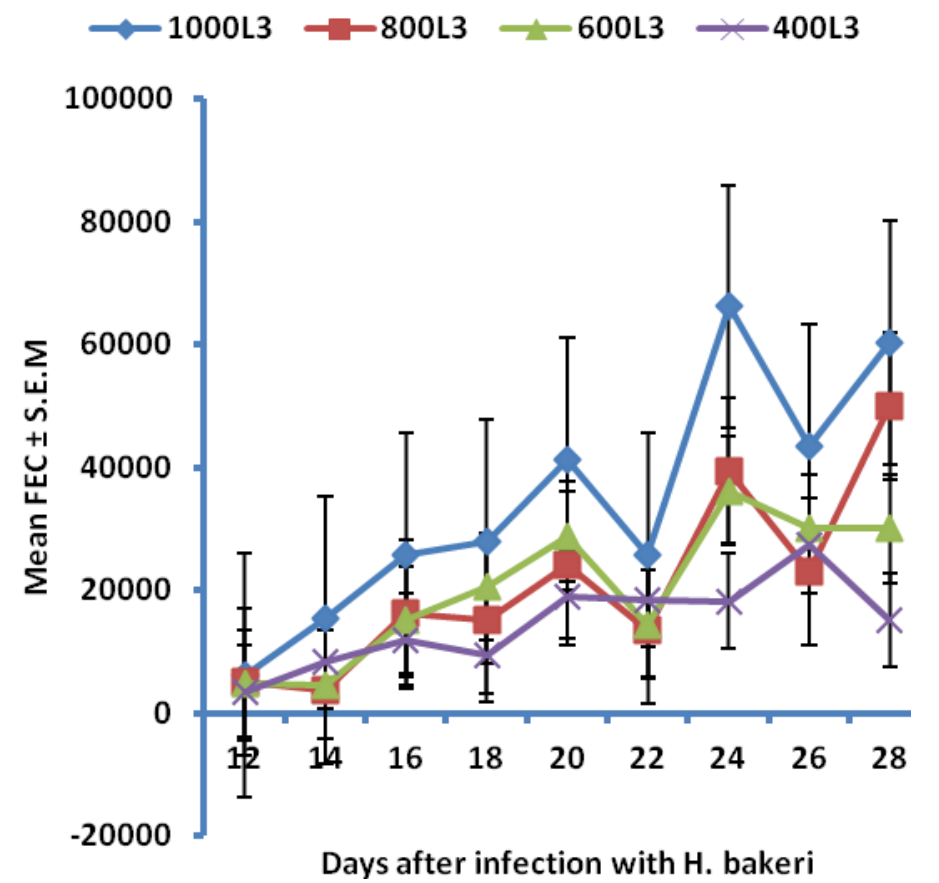

Fig 1. Mean faecal egg counts of mice infected with 400 - 1000 L3 H. bakeri.

Worm burden

The WB followed a similar pattern as observed in the FEC being highest for the 1000L3 dose, moderate for the 600 and 800L3 and and least for the 400L3 Fig 2). However, while theWB of the 1000L3 dose group was clearly higher than that of the groups, there was no clear cut diffrence between the 800, 600 and 400L3 dose groups. 


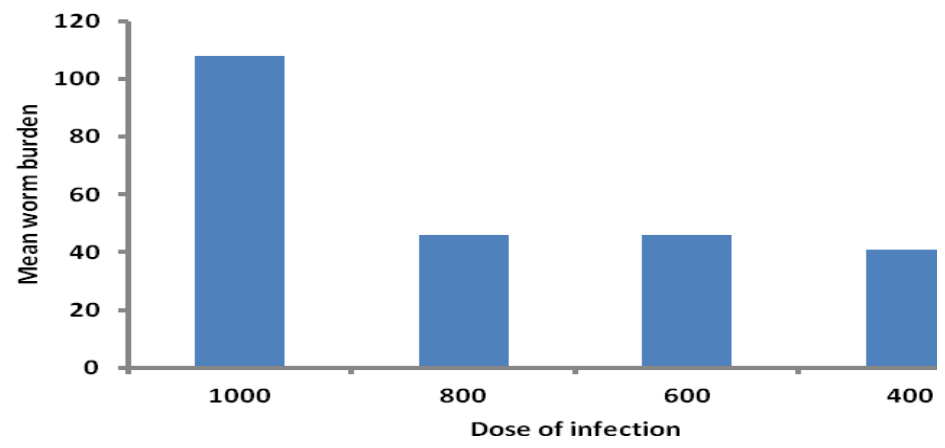

Fig 2. Mean worm burden of mice infected with 400 - 1000 L3 H. bakeri.

\section{Packed cell volume}

PCV of infected mice dropped in comparison to that of the uninfected control mice (Fig 1). The drop in PCV progressed as the experiment progressed being least on D28 when the experiment ended. The drop in PCV of the infected mice was highly significant (0.002) in comparison to the uninfected control mice.

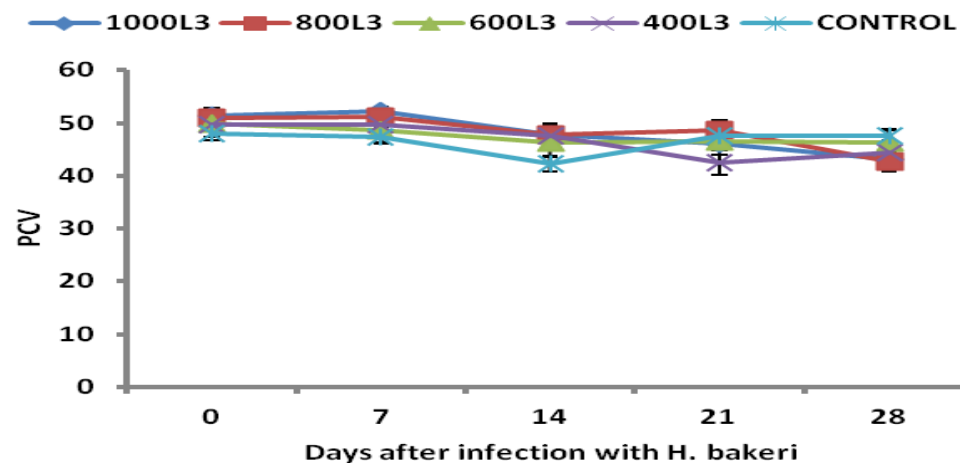

Fig 3. Mean PCV of mice infected with $400-1000$ L3 H. bakeri.

\section{Bodyweights}

Bodyweights fluctuated markedly with no clear cut pattern (Fig 4). However, most animals ended up with a positive weight gain apart from mice of the 600L3 dose group that had a final bodyweight slightly lower than their initial bodyweight. However, there was no significant difference $(P=0.38)$ in bodyweights between groups.

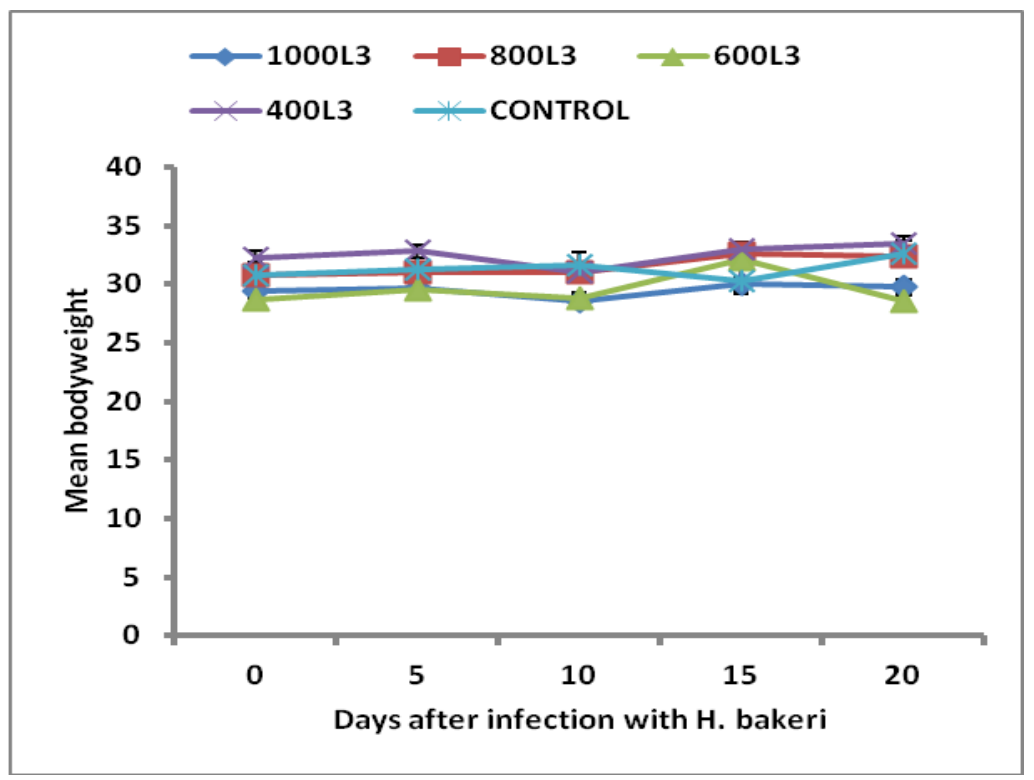

Fig 4. Mean bodyweight of mice infected with $400-1000$ L3 H. bakeri. 


\section{Mortalities}

No mortality occurred throughout the experiment.

\section{Experiment II}

In experiment I all the mice infected with 200-1000 L3 H. bakeri survived till the end of the experiment on D28. This necessitated the running of the second experiment using higher doses of $H$. bakeri in order to establish a dose that can cause mortality.

Experimental design

Twenty four eight-week old mice weighing averagely $29 \mathrm{~g}$ at the start of the study were were used. The mice were managed and fed as described in Experiment I. The procedures were as conducted in experimrnt I. The design of the experiment is shown on Table 2 .

Table2. Infection of male and female outbred albino mice with graded single doses of H. bakeri L3.

\begin{tabular}{|c|c|c|c|c|c|c|c|c|}
\hline Group & $\begin{array}{l}\text { Number } \\
\text { mice }\end{array}$ & of & Sex & $\begin{array}{l}\text { Age } \\
\text { mice/weeks }\end{array}$ & of & $\begin{array}{l}\text { Dose of } \mathrm{Hb} \\
\mathrm{L} 3\end{array}$ & $\begin{array}{ll}\text { Day of } \\
\text { infection }\end{array}$ & $\begin{array}{l}\text { Day of Necropsy (Post } \\
\text { infection) }\end{array}$ \\
\hline Infected & 3 & & $\mathrm{M}$ & 8 & & 1200 & 0 & 21 \\
\hline Infected & 3 & & M & 8 & & 1500 & 0 & 21 \\
\hline Infected & 3 & & M & 8 & & 2000 & 0 & 21 \\
\hline Infected & 3 & & M & 8 & & 2500 & 0 & 21 \\
\hline Infected & 3 & & M & 8 & & 3000 & 0 & 21 \\
\hline Infected & 3 & & M & 8 & & 3500 & 0 & 21 \\
\hline Uninfected & 3 & & M & 8 & & 4000 & 0 & 21 \\
\hline Uninfected & 3 & & M & 8 & & 0 & 0 & 21 \\
\hline
\end{tabular}

$\mathrm{M}=$ Male. $\mathrm{Hb}=$ H. bakeri. $\mathrm{L} 3$ = Third larval stage (infective larvae).

\section{Results}

Faecal egg cunts

Faecal egg counts rose fairly steadily following patency from D11 to D21 when the experiment ended (Fig 5). The 1200 and 1500 L3 dose groups had the highest FEC. Contrary to Experiment I FEC did not follow any strict pattern instead the lower dose groups tended to have higher FEC. However, the difference in FEC between groups was not significant $(P=0.65)$. Beginning from the $2000 \mathrm{~L} 3$ dose group particularly there was no longer any proportionate increase in FEC with increasing dose of infection.

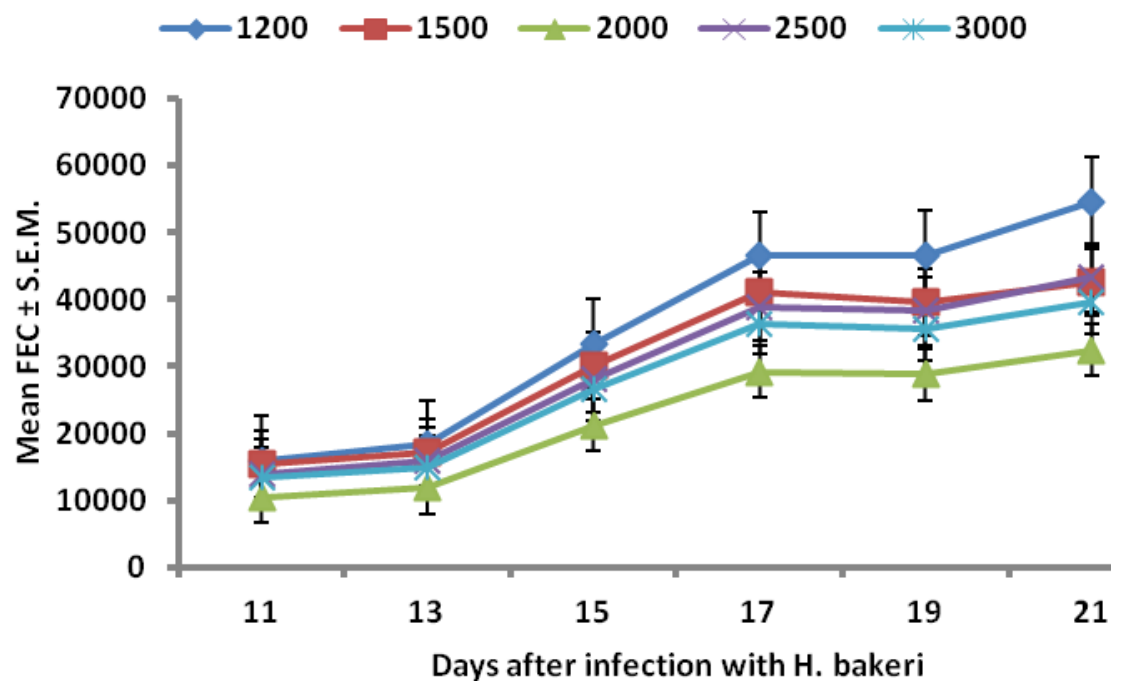

Fig 5a. Mean faecal egg counts of mice infected with 1200 - 3000 L3 H. bakeri 


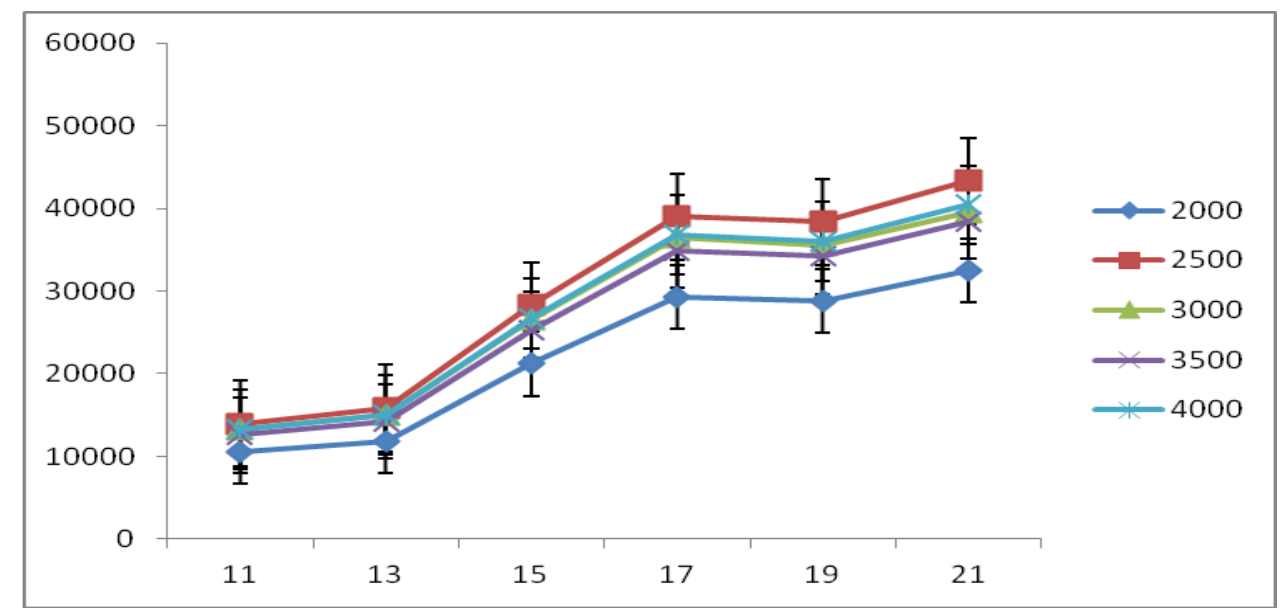

Fig5b. Mean faecal egg counts of mice infected with $2000-4000$ L3 H. bakeri

\section{Worm burden}

Worm burden varied but generally incareased with increasing dose of H. bakeri (Fig 6). The increase in WB with increasing dose of $H$. bakeri was fairly steady for 1200, 1500 and $2000 \mathrm{~L} 3$.

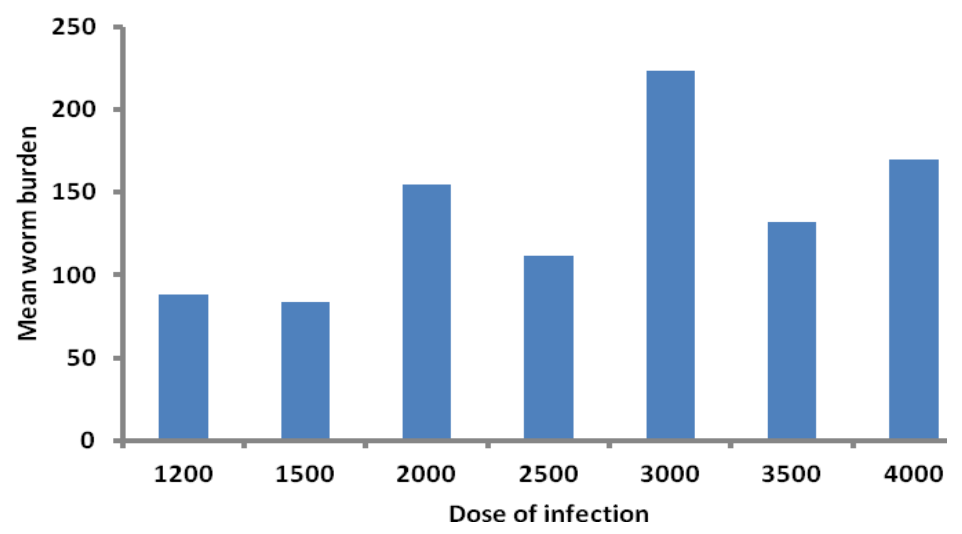

Fig 6. Mean worm burden of mice infected with H. bakeri infected with 1200 - 4000 L3 H. bakeri.

Packed cell volume

Apart from the 1200 L3 infected mice that experienced only a mild drop in PCV on D10, infected mice had sharp drops in PCV when compared to the uninfected control mice and the difference between groups was significant $(P=0.007)$ ig 7\}. These decline in PCV continued to D20. The declines in PCV in Experiment II were severer than those recorded in Experiment I indicating that PCV changes overall depended on dose of infection.

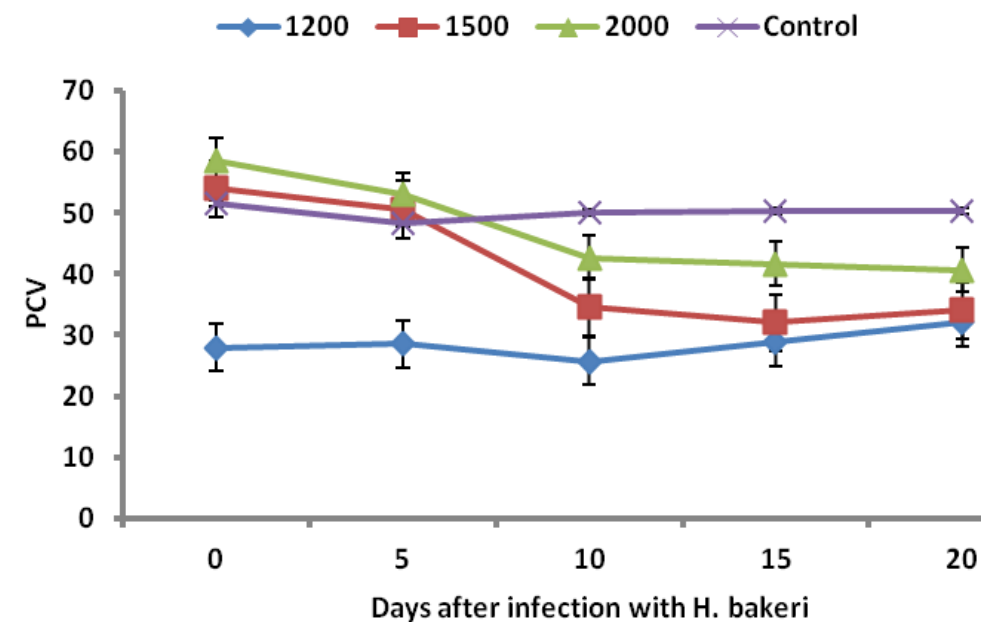

Fig 7a. Mean PCV of mice infected with $1200-2000$ L3 H. bakeri. 


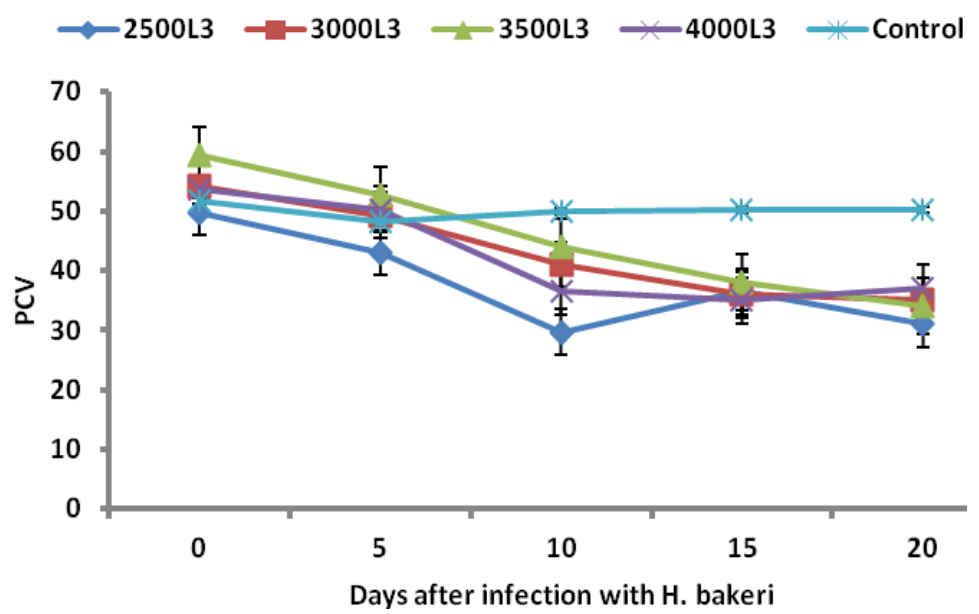

Fig 7b. Mean PCV of mice infected with 2500 - 4000 L3 H. bakeri.

\section{Bodyweights}

There was a steady gain in the bodyweight of uninfected mice up to D20 (Fig 8), while the infected mice lose weights and the difference in bodyweights was significant $(P=0.001)$ between groups (Fig 8).

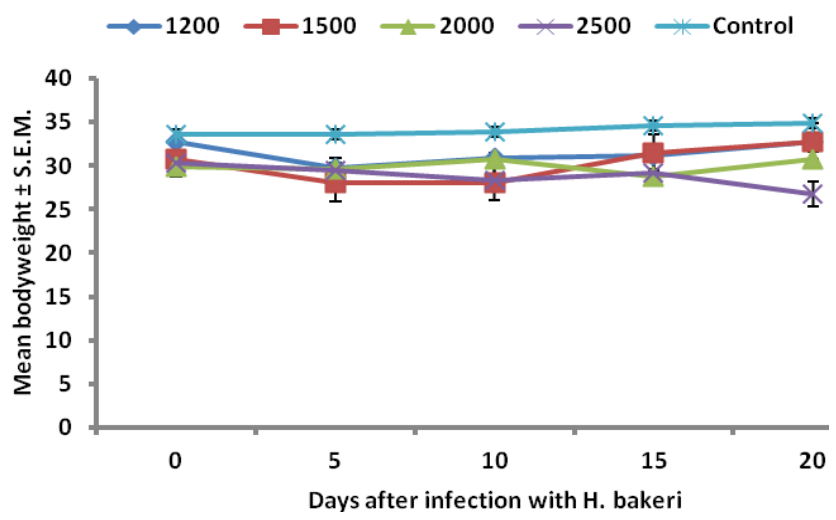

Fig 8a. Mean bodyweights of mice infected with $1200-2500$ L3 H. bakeri.

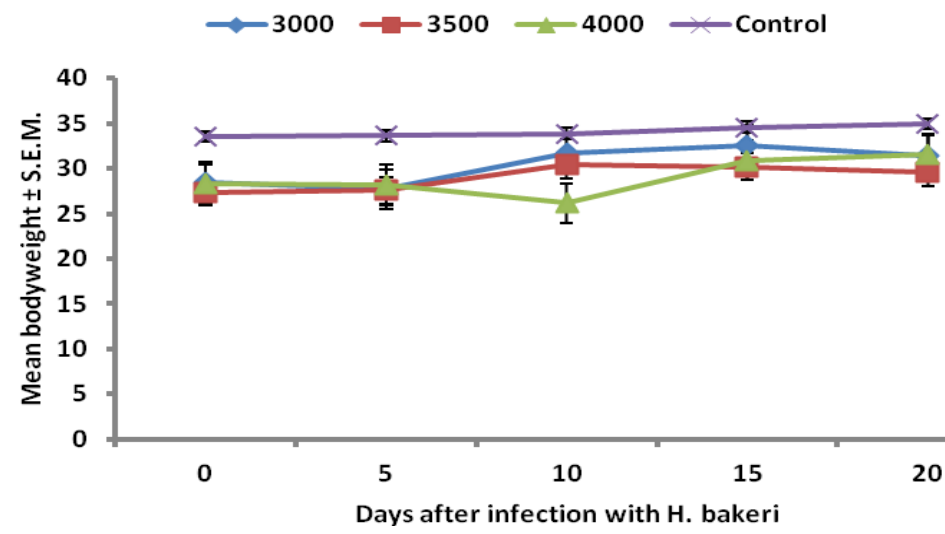

Fig 8b. Mean bodyweights of mice infected with $2500-4000$ L3 H. bakeri.

\section{Mortalities}

Seven mortalities were recoreded before the end of the experiment. The experiment was terminated a week earlier compared to Experiment I because of the high morbity and mortality rate. All mice infected with doses ranging from $1200-2000 \mathrm{~L} 3 \mathrm{H}$. bakeri survived to the end of the study on D21. One of the mice infected with $2500 \mathrm{~L} 3$ died on D15, 2 mice of the $3000 \mathrm{~L} 3 \mathrm{H}$. bakeri dose died on D10, 2 mice of the $3500 \mathrm{~L} 3$ dose died 
on D11 while 2 mice 4000 L3 dose died on D10 and D11. Mice infected with H. bakeri doses of 2500 L3 and above were usually diarrhoec before death and their perianal areas were usually matted with bloody or dark red faeces (Plate 1). Such mice just before death stopped feeding and had dull coats preferring quiet spots to avoid cage mates and remained docile at such locations.

At autopsy, the intestines of dieing mice or generally mice infected with as high as $2500 \mathrm{~L} 3 \mathrm{H}$. bakeri and above had their small intestines engorged with bloody ingesta and this bloody contents could be readily noticed from the serosal surface of the intestine before incision (Plate 2). On incision the lumen of the intestine was filled with bloody ingesta/faeces.
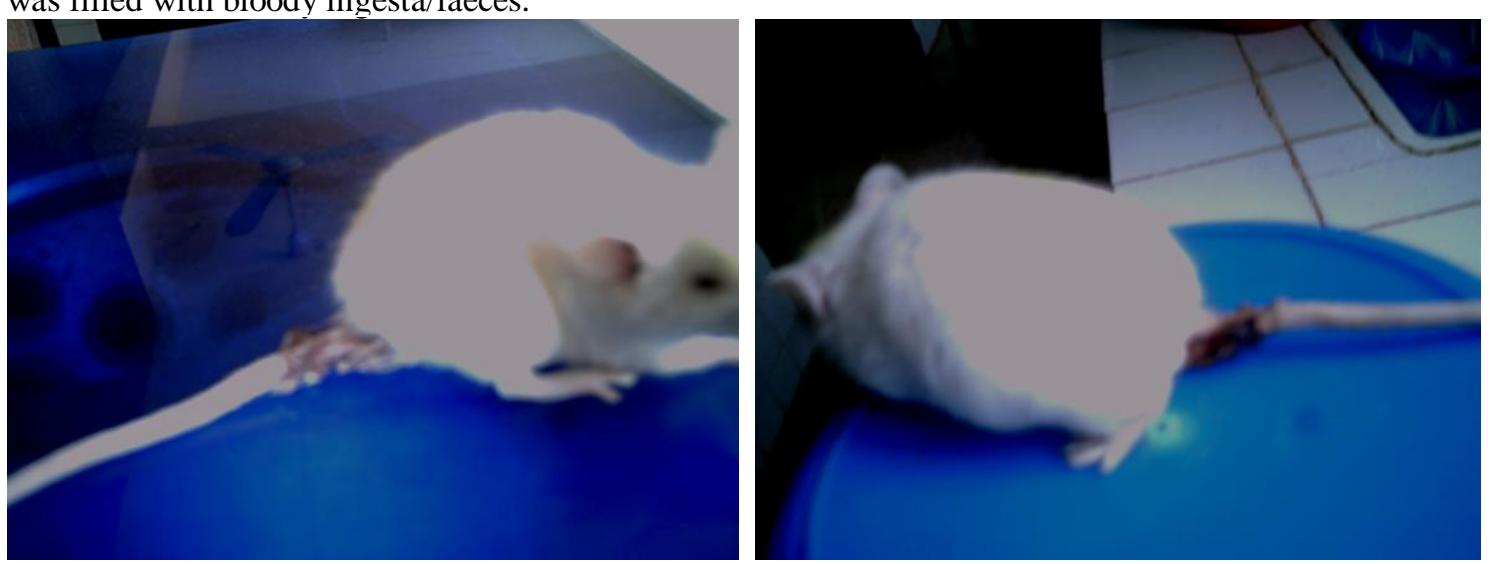

Plate 1.Docile H. bakeri-infected mice with the perineum matted with dark red faeces.

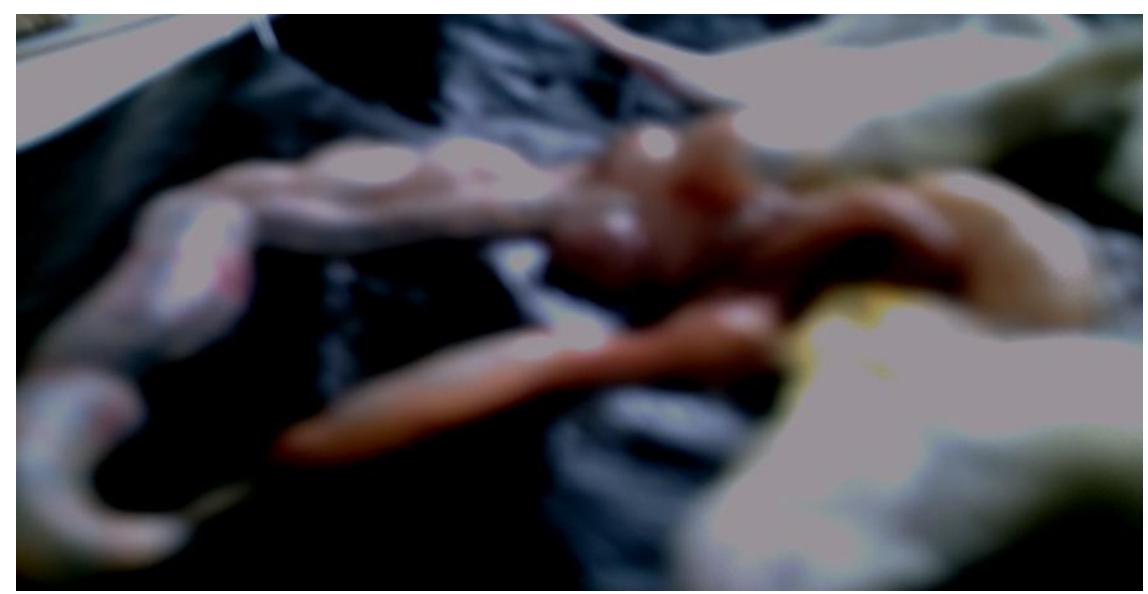

Plate 2. Intestine of mice at autopsy engoreged with bloody ingesta noticeable from the serosal surface.

\section{Discussion}

Though only proportionate to a certain point, there was generally an 'increase dose increase FEC and WB response pattern'. Also observed was an 'increase dose increase in PCV and bodyweight decline'. This was an indication that these parameters were dependent on the infection dose level. This fact was supported by the high morbidity and high mortality rates that occured at higher doses. The results demonstrated that outbred albino mice can survive $H$. bakeri infections with doses up to 2000 L3 per mouse. No mortality was recorded in Experiment I where infections with dose levels up to $1000 \mathrm{~L} 3 \mathrm{H}$. bakeri were given per mouse. However, mortalities occured in Experiment II where mice were infected with 2500 to $4000 \mathrm{~L} 3 \mathrm{H}$. bakeri. The pathogenicity of $H$. bakeri to its outbred albino mouse host is thus dose dependent. This finding is similar to earlier reports that parasite virulence often increase when the dose of infection is increased (Keymer, 1982; Asworth et al., 1996).

The ceiling dose that could be used for studies of $H$. bakeri infection in mice is therefore $2000 \mathrm{~L} 3$ because any dose level above this could be fatal to the mouse host. The FEC and WB showed striking patterns in that a dose related response in which FEC tended to increase with increase in the dose of infection up to the dose level of 1500 L3 was observed. However, as dose levels increased beyond 1500 L3 there were still increments in FEC and WB but there were no further regular patterns in the increments. This may be attributed partly to an overcrowding effect leading to space and nutrient availability pressure at their predilection site in the proximal small intestine resulting in low fecundity or outright expulsion of the worms due to lack of attachment sites. In high dose homologous infections, GI nematode parasites compete for space and such 
competition is detrimental to the survival of the parasites (Holmes, 1983). It has also been shown that parasite dose is inversely proportional to worm fecundity (Anderson and May, 1982; Keymer, 1982; Michael and Bundy, 1989; Asworth et al., 1996). It is also possible that the much higher doses, 2000 to 4000 L3 could have stimulated great enough immune response in the mice quickening the expulsion of worms (Bezubik et al., 1988; Musongong et al., 2004). However, more worms were generally recovered from mice infected with higher doses of $H$. bakeri.

Infected mice developed anaemia and this generally became severer both as the experiment progressed and with increasing dose of infection. H. bakeri is a haematophagous nematode and causes loss of blood through blood sucking and haemorrhage of the duodenal mucosa. Mice infected with H. bakeri doses above 2000 L3 showed severe haemorrhage with bloody ingesta at autopsy and their faeces antemortem were dark red due to the presence of blood from mucosal haemorrhage. Juvenile (5-week old) mice infected with as low dose as 200 L3 of H. bakeri were reported to have bloody ingesta, passed dark red faeces and suffered great mortalities (Ngongeh, 2011). Declines in PCV were more obvious in Experiment II especially in mice infected with 1500 L3 and above. Researchers working with the H. bakeri-mouse model may chose working doses in the range 100 to 2000 L3 H. bakeri. Ngongeh (2011) worked with the dose levels 100, 200 and 300 L3 H. bakeri in outbred albino mice and reported that even $100 \mathrm{~L} 3$ induced detectable pathology in the mice. Therefore, given the pathogenic nature of the parasite in mice, high infection dose levels may only be used where serious pathogenic effects are desired. The 2000 L3 ceiling dose is just a level that must not be exceeded if mortalitis are to be avoided.

The results therefore suggest that adult mice up to 8 week-old can survive infection with $2000 \mathrm{~L} 3 \mathrm{H}$. bakeri and below. The infection dose of $2000 \mathrm{~L} 3$ is therefore the ceiling dose of $H$. bakeri in such adult or older mice. Dose levels as high as $2500 \mathrm{~L} 3$ and above were lethal to the mice. In designing experiments with the $H$. bakeri-mouse model for the study of GI nematode parasites only doses of 2000 L3 and below should be considered in adult mice. Infection doses of H. bakeri greatrer than 2000 L3 may lead to earlier death of the parasite when enough data might not have been taken.

\section{References}

[1]. Anderson, R.M. and May, R.M. (1982). Coevolution of hosts and parasites. Parasitology. 85: 411-26.

[2]. Asworth,R.M., Kennedy, C.R., Blanc, G. (1996). Density dependent effects of Anguillicola crassus. (Nematoda) within and on its copepod intermediate hosts. Parasitology. 113: 303-309.

[3]. Bezubik, B., Wedrychovicz, H. and Wojciechowska. (1988). Trichostrongylus colubriformis in rabbits: some quantitative aspects and pathogenesis of single and multiple infections. Acta Parasitologica Polonica. 33: 133-142.

[4]. Ehrenford, F. (1954). Effects of dietary protein on the relationship between laboratory mice and the nematode Nematospiroides dubius. Journal of Parasitology. 40: 486.

[5]. Fakae, B.B. (1993). Conjoint Heligmosomoides polygyrus and Trypanosoma congolense infection in mice. PhD Thesis. The University of Edinburgh. Xiii+219pp

[6]. Fakae, B.B (2001). Primary infection of TO outbred Mice with differing intensities of H. polygyrus infective larvae. International Journal of Agricultural Science and Biological Science.. 1: 1-4.

[7]. Flemming, M.W. (1988). Size of inoculums dose regulates in part worm burdens, fecundity and lengths in ovine Haemonchus contortus infections. Journal of Parasitology. 74: 975-978.

[8]. Holmes, J.C. (1983). Site selection by parasitic helminths: interspecific interactions, site segregation and their importance to the development of the helminth communities. Canada Journal of Zoology, 51: 333-347.

[9]. Jennifer C. C, Simon A. B., Lutz B., Ilias K., Judith E. A. and Jos G. M.H. (2011). Interactive effects of protein nutrition, genetic growth potential and Heligmosomoides bakeri infection pressure on resilience and resistance in mice. Parasitology. 138: 1305-1315

[10]. Keymer, A.E. (1982). Density-dependent mechanisms in the regulation of intestinal helminth populations. Parasitology. 84: 573587 .

[11]. Keymer, A. E. and Tarlton, A. B. (1991). The population dynamics of acquired immunity to Heligmosomoides polygyrus in the laboratory mouse: strain, diet and exposure. Parasitology. 103: 121-126.

[12]. Michael, E. and Bundy, D.A. (1989). Density dependence in establishment, growth and worm fecundity in intestinal helminthiasis: the population bilogy of Trichuris muris (Nematoda) infection in CBA/Ca mice. Parasitology. 98: 451-458.

[13]. Ministry of Agriculture, Fisheries and Food Agricultural Development and Advisory Service (MAFF). (1977). Manual of Veterinary Parasitological Laboratory Techniques. Technical Bulletin No. 18, HMSO, London,pp 36-37.

[14]. Musongong, G.A., Chiejina, S.N., Fakae, B.B., and Ikeme, M.M. (2004). The response of tropical breed of domestic rabbit, Oryctolatus cuniculus, to experimental infections with Trichostrongylus colubriformis. Journal of Helminthology. 78: $249-257$.

[15]. Ngongeh, L.A. A laboratory model for the preliminary study of some aspects of gastrointestinal nematode infections of small ruminants. Ph.D Thesis. University of Nigeria, Nsukka. 2011; P. 116.

[16]. Ngongeh, L.A., Ndofor-Foleng, H.M., Fakae, B.B. (2011). Comparison of mean faecal egg counts and worm burdens of male mice infected with Heligmosomoides bakeri with those of their first filial (F1) offspring. Continental Journal of Veterinary sciences. 5: 610 .

[17]. Roland, R.R., Diether, E. and Sebastian, B. (2002). Dose-dependent infection rates of parasites produce the Allee effect in epidemiology. Proceedings of Biological sciences. 269: 271-279.

[18]. Soulsby, E.J.L. (1982). Helminths, arthropods and protozoa of domesticated animals. $7^{\text {th }}$ edition. Balliere Tindal, London.

[19]. Taira, N, Nakamura, Y, Kalihira, H and Ura, S. (1992). Fatal strongylidosis in calves in the sandust litter confinement pens in Japan. $15^{\text {th }}$ Int. Conf. of the Association for the Advancement of Vet. Parasitology. August 30-Sept. 2, 1995. Yokahoma Japan. 